\title{
Nitrogen fertilization in the contents of secondary compounds in cassava cultivars
}

\section{Adubação nitrogenada nos teores de compostos secundários em cultivares de mandioca industrial}

\author{
Diego Gazola ${ }^{1 *}$; Claudemir Zucareli²; Rudiney Ringenberg ${ }^{3}$; José Perez da Graça ${ }^{4}$; \\ Clara Beatriz Hoffmann-Campo ${ }^{3}$
}

\begin{abstract}
The production of chemical substances is a strategy of plants to defend against the attack of pest insects. The synthesis of secondary compounds in plants is influenced by genotype and cultural management, such as the use of nitrogen fertilizers. Thus, the objective of this work is to evaluate the effect of doses of nitrogen fertilizer over time on the production of secondary compounds in two industrial cassava cultivars. The experiment was carried out in a greenhouse $\left(25 \pm 5^{\circ} \mathrm{C}\right)$ of Embrapa Soybean in Londrina, Paraná, with the cultivation of potted plants (41) in a $2 \times 4 \times 3$ factorial scheme, with five replications. Two genotypes of industrial cassava ('Baianinha' and 'Caiuá') and four different nitrogen doses $(0,30$, 60 , and $90 \mathrm{~kg} \mathrm{ha}^{-1}$ ) were used, with sampling at 15,30, and $45 \mathrm{~d}$ after fertilization. Nitrogen fertilization was performed $50 \mathrm{~d}$ after sprouting. In the apical leaves, the levels of rutin, caffeic, p-coumaric and ferulic acids were evaluated in a high performance liquid chromatograph (HPLC). Exploratory analyses were performed on the data variables to verify the assumptions for analysis of variance (ANOVA), such as the independence and normality of errors, homogeneity of treatment variances and non-additivity of the model (they were submitted to analysis of homogeneity and normality, respectively. After these tests, ANOVA and Tukey's test $(p \leq 0.05)$ were performed. For the quantitative data concerning the $\mathrm{N}$ rates, regression study analyzes were performed. The Caiuá cultivar was found to have a higher ferulic acid content. The caffeic acid content decreased over time after the application of $\mathrm{N}$ in both cultivars. The rutin content in both cultivars did not increase with an increase in nitrogen dose. At a dose of $90 \mathrm{~kg}$ ha $^{-1}$, both cultivars presented a lower p-coumaric acid content after $30 \mathrm{~d}$.

Key words: Caffeic acid. P-coumaric acid. Ferulic acid. Defensive compounds. Manihot esculenta. Rutin.
\end{abstract}

\section{Resumo}

A produção de substâncias químicas é uma estratégia de defesa das plantas ao ataque de insetos praga. A síntese de compostos secundários em plantas é influenciada pelo genótipo e pelo manejo cultural, como o uso de fertilizantes nitrogenados. Deste modo, o trabalho tem como objetivo avaliar o efeito de doses de nitrogênio sobre a produção de compostos secundários em duas cultivares industriais de mandioca ao longo do tempo. $\mathrm{O}$ experimento foi realizado em casa de vegetação semiclimatizada $\left(25^{\circ} \pm 5^{\circ} \mathrm{C}\right) \mathrm{da}$

1 Dr. em Agronomia, Universidade Estadual de Londrina, UEL, Londrina, PR, Brasil. E-mail: gazolad@gmail.com

2 Prof. Dr., Adjunto, Centro de Ciências Agrárias, UEL, Londrina, PR, Brasil. E-mail: claudemircca@uel.br

3 Pesquisadores, Empresa Brasileira de Pesquisa Agropecuária, EMBRAPA Soja, Londrina, PR, Brasil. E-mail: rudiney. ringenberg@embrapa.br; clarabeatriz.campo@embrapa.br

${ }^{4}$ Pós-doutorando, Empresa Brasileira de Pesquisa Agropecuária, EMBRAPA Soja, Londrina, PR, Brasil. E-mail: perezparr@ gmail.com

Author for correspondence 
Embrapa Soja em Londrina/PR, com cultivo das plantas em vasos (4 litros), em esquema fatorial 2x4x3, com cinco repetições. Foram utilizados dois cultivares de mandioca industrial (Baianinha e Caiuá) e quatro doses de nitrogênio $\left(0,30,60\right.$ e $\left.90 \mathrm{~kg} \mathrm{ha}^{-1}\right)$, com avaliações aos 15, 30 e 45 dias após a adubação. A adubação nitrogenada foi realizada com ureia, 50 dias após a brotação das manivas. Nas folhas apicais foram avaliados os teores de rutina e de ácidos caféico, p-cumárico e ferúlico em cromatógrafo líquido de alto desempenho (HPLC). Foram realizadas análises exploratórias com os dados das variáveis e verificado os pressupostos para a Análise de Variância (ANOVA) como a independência e normalidade dos erros, homogeneidade de variâncias dos tratamentos e não-aditividade do modelo (SHAPIRO; WILK, 1965; PARENTE, 1984; BURR; FOSTER, 1972; TUKEY, 1949), respectivamente. Após estes testes foram realizadas as Anovas e os testes de comparações múltiplas de médias por Tukey $(0,05)$, (STEEL; TORRIE, 1960). Para os dados quantitativos referentes as doses de $\mathrm{N}$ foi realizada análises de regressão. A cultivar Caiuá acumulou maior teor de ácido ferúlico. O teor de ácido caféico diminui ao longo do tempo após a aplicação de $\mathrm{N}$ em ambas cultivares. $\mathrm{O}$ teor de rutina nas cultivares de mandioca Baianinha e Caiuá não foi influenciada com acréscimo das doses de nitrogênio. Na dose de $90 \mathrm{~kg} \mathrm{ha}^{-1}$ as cultivares apresentam menor teor de ácido p-cumárico após os 30 dias.

Palavras-chave: Ácido caféico. Ácido p-cumárico. Ácido ferúlico. Compostos de defesas. Manihot esculenta. Rutina.

\section{Introduction}

Cassava production in Brazil plays an important socioeconomic role, with crops concentrated in areas belonging to small producers, that are characterized by the use of few inputs and low levels of technology. This is primarily a result of the plant's ability to develop and produce in soils with low fertility (CARVALHO; FUKUDA, 2006). The crop absorbs large amounts of nutrients, and practically all absorbed nutrients are translocated to the tuberous roots (MATTOS; BEZERRA, 2003).

In general, $\mathrm{N}$ is the most required nutrient by crops, and has numerous functions, such as promoting the formation and development of flower and fruit buds and increasing the size of the vegetative parts and protein content. In addition, it is a structural component of amino acids and proteins, nitrogenous bases and nucleic acids, enzymes, co-enzymes and vitamins, pigments, and some secondary metabolites (MALAVOLTA et al., 1997).

In addition to the effects of $\mathrm{N}$ on the growth, development, and yield performance of plants, it is involved in the synthesis of secondary compounds and amino acids in plants. In cassava, a greater availability of $\mathrm{N}$ in the soil also favors the synthesis of cyanogenic glycosides such as linamarin and lotaustralin (SOLOMONSON; BARBER, 1990; VETTER, 2000).

In a study conducted by Oliveira et al. (2012) it was concluded that the hydrocyanic acid $(\mathrm{HCN})$ content in the 'Aciolina' cultivar had a positive response to increased doses of topdress $\mathrm{N}$ (30, 60,150 , and $\left.330 \mathrm{~kg} \mathrm{ha}^{-1}\right)$. The synthesis of plant secondary compounds is more influenced by agricultural practices (fertilizers, application of manure, and burning of crop residues) than by seasonal factors. The synthesis of alkaloids and cyanogenic glycosides increases with an increased availability of nitrogen fertilizers, whereas the synthesis of phenolic compounds increases when the plant is cultivated in a soil poor in nitrate fertilizer (GERSHENZON, 1984; WATERMAN; MOLE, 1989).

Phenolic compounds are a class of plant secondary metabolites with recognized biological activity. They provide plants protection against attacks by pest insects and pathogens (LORENZI et al., 2003; SCHALLER, 2008). These compounds may also serve as a warning to generalist pests that the plant is unpalatable (ZAGROBELNY et al., 2004). Santos et al. (2008) observed that the higher the HCN content in the roots of cassava the lower the incidence of nymphs and adults of Vatiga 
illudens Drake (Hemiptera: Tingidae). Calatayud and Múnera (2002) concluded that the addition of the flavonol rutin to an artificial diet reduced the growth and development of the mealybug insect Phenacoccus manihoti Matile-Ferrero (Hemiptera: Pseudococcidae).

In cassava, the mealybug insect that feeds on the aerial part of the plant, P. manihoti, is one of the most severe pests attacking this crop worldwide (PARSA, et al., 2012), and because there are no effective control methods, nor a registered chemical product for use on cassava, implementing an appropriate and efficient management method is a priority to achieve high crop yields.

The Caiuá (Olho junto) cassava cultivar, which is widely cultivated on sandy soils in the northwest of Paraná, is highly susceptible to the mealybug insect P. Manihoti when grown in the field, exhibiting explosions of populations especially during the second crop cycle. However, under laboratory conditions, this cultivar has been shown to be moderately resistant to this insect. The Baianinha cultivar, which is grown in the western region of Paraná and is better adapted to more fertile and clayey soils, was susceptible to $P$. manihoti under laboratory conditions, but high insect infestations were not observed in the field (TAKAHASHI; GONÇALO, 2005; RHEINHEIMER, 2013).

These contradictory data may be associated with the nutrient conditions of the soils in which these cultivars are traditionally grown. Depending on the time of application, nitrogen fertilization may increase or decrease the production of secondary compounds, thus making the plant more tolerant or susceptible to pests, with responses varying according to the genotype.

In addition to inducing plants to produce defense compounds, nitrogen fertilization may decrease the natural physical barriers of plants. Therefore, inducing the production of secondary compounds may be a strategy for crop management because it has an inhibitory effect on pest insects, and keeps their population below the level of economic damage, in addition to reducing yield losses, and thus may be included as an integrated pest management tool (BELLOTTI et al., 1999; PIETROWSKI et al., 2010).

In this context, the objective of the present study was to assess the effect of nitrogen fertilization over time on the production of secondary metabolism compounds in two cultivars of cassava.

\section{Material and Methods}

The experiment was conducted in the semicontrolled climate greenhouse of Embrapa Soja in Londrina Paraná $\left(23^{\circ} 18^{\prime} 36^{\prime \prime} \mathrm{S}\right.$ and longitude $51^{\circ} 09^{\prime} 46^{\prime \prime} \mathrm{W}$ ) during 2016 , at a temperature of 25 $\pm 5^{\circ} \mathrm{C}$. The experiment was implemented using cassava stems from a commercial agricultural area in the west and northwest regions of Paraná; these were measured and cuttings of approximately 10 $\mathrm{cm}$ long with five to seven buds were used. Vertical planting was performed using the cassava stems in pots with a capacity of $5 \mathrm{~L}$ of soil. Water was provided to plants using drip irrigation thrice a day (volume of $400 \mathrm{~mL} \mathrm{~d}^{-1}$ pot $^{-1}$ ). The chemical analysis of the soil used as a substrate led to the following results: $\mathrm{P}=16.89 \mathrm{cmol} / \mathrm{dm}^{3} ; \mathrm{pH}\left(\mathrm{CaCl}_{2}\right)=5.5 ; \mathrm{Al}=$ $0 \mathrm{cmolc} / \mathrm{dm}^{3} ; \mathrm{H}+\mathrm{Al}=4.61 \mathrm{cmolc} / \mathrm{dm}^{3} ; \mathrm{Ca}=6.99$ $\mathrm{cmolc} / \mathrm{dm}^{3} ; \mathrm{Mg}=1.35 \mathrm{cmolc} / \mathrm{dm}^{3} ; \mathrm{K}=0.85 \mathrm{cmolc} /$ $\mathrm{dm}^{3} ; \mathrm{V} \%=66.59 ; \mathrm{CEC}=13.8 ; \mathrm{MO}=3.15 \mathrm{~g} / \mathrm{dm}^{3}$.

The experimental design was completely randomized, with a $2 \times 4 \times 3$ factorial arrangement, using two cultivars of cassava (Baianinha and Caiuá) and four doses of topdressed $\mathrm{N}(0,30,60$, and $\left.90 \mathrm{~kg} \mathrm{ha}^{-1}\right)$. Leaf collections for analysis were performed at three different times $(15,30$, and 45 $\mathrm{d}$ after nitrogen fertilization) with five repetitions each, making up a total of 120 pots. Nitrogen fertilization was applied as urea to moist soil in all pots, according to the determined dose, $50 \mathrm{~d}$ after the sprouting of cassava stem cuttings. P and $\mathrm{K}$ fertilization was not performed because the soil analysis showed that these elements were not 
required. Two fully developed apical leaves from each repetition were used in the assessments. The leaves were cut, labeled, wrapped in aluminum paper, and immediately frozen in liquid nitrogen. They were subsequently sent to the Laboratory of Chemical Ecology of Embrapa Soja, Londrina, Paraná, and stored in an ultra-freezer at $-86{ }^{\circ} \mathrm{C}$.

For sample preparation in the laboratory, the leaves were removed from the ultra-freezer, ground in a mortar with liquid nitrogen, transferred to a 15$\mathrm{mL}$ Falcon tube, and weighed. The samples were added to $5 \mathrm{~mL}$ of methanol $(\mathrm{MeOH}$; $90 \%)$ and the extracts were vortex-mixed for 10 seconds, placed in an ultrasonic bath for $20 \mathrm{~min}$, and centrifuged at 5,650 rpm for $10 \mathrm{~min}$ at $4{ }^{\circ} \mathrm{C}$. The supernatants were collected with a Pasteur pipette, transferred to glass tubes, and vacuum-dried. The samples were resolubilized in methanol $(80 \% ; 1.5 \mathrm{~mL})$ and centrifuged for $10 \mathrm{~min}$ at $10,000 \mathrm{rpm}$ at $4{ }^{\circ} \mathrm{C}$. The samples were then filtered through Acrodisc ${ }^{\circledR}$ syringe filters with a $0.45 \mu \mathrm{m}$ membrane (Millipore ${ }^{\circledR}$ ) and transferred to the automatic injector vials of the high-performance liquid chromatography (HPLC) system (Shimadzu Prominence). The metabolic extracts from the samples were analyzed using a $\mathrm{C} 18$ reversed-phase column ( $250 \mathrm{~mm}$ length and $4.6 \mathrm{~mm}$ internal diameter, $5 \mu \mathrm{m}$ particles). Aliquots of $20 \mu \mathrm{L}$ were automatically injected in the system equipped with a CBM-20A system controller, a SPD-20A detector, a DGU 20A5 degasser, a LC-20AT pump, a SIL-20A automatic sampler, and a CTO 20A column oven. The mobile phase was composed of two solvents: (A) 2\% acetic acid (HOAc) and (B) a mixture of $\mathrm{MeOH}$, acetic acid, and Milli- $\mathrm{Q}^{\circledR}$ water (MeOH:HOAc:H2O; 18:1:1). The initial condition of the linear gradient program used in the analysis was $75 \%$ of $A$ and $25 \%$ of B, which was then changed to the reverse after $40 \mathrm{~min}$, i.e., $25 \%$ of $\mathrm{A}$ and $75 \%$ of $\mathrm{B}$, which was maintained for $5 \mathrm{~min}$. The program returned to the initial condition for $5 \mathrm{~min}$ before the next injection to rinse the column. The flow rate of the solvent was $1 \mathrm{ml} / \mathrm{min}$ and detection was carried out in the UV region at a selected wavelength was $260 \mathrm{~nm}$. The identification and quantification of the compounds were performed by comparing the HPLC column retention times and the peaks in the spectra obtained in the experiment with those of standard phenolic acids and flavonoids. The areas of each peak in the spectra were recorded, and the results were corrected using the initial weight of the plant tissue of each sample converted into $\mu \mathrm{g} / \mathrm{g}$.

The data regarding the variables were submitted to tests to analyze the homogeneity of variance (BURR; FOSTER, 1972), normality of the residuals using the Shapiro-Wilk test (SHAPIRO; WILK, 1965), and non-additivity of the model (TUKEY, 1949). The transformation was performed for data regarding ferulic acid and p-coumaric acid. Subsequently, the results were submitted to an analysis of variance (ANOVA) test, and the means were compared using Tukey's test $(<0.05)$. The data regarding the doses of $\mathrm{N}$ were submitted to regression analysis. The statistical software systems used were Statistical Analysis System (SAS, 2009) version 9.2, and SISVAR, version 5.0.

\section{Results and Discussion}

The effect of the triple interaction between the cultivars, doses of $\mathrm{N}$, and time after application of $\mathrm{N}$ on the concentrations of rutin and p-coumaric acid was significant. Ferulic acid content was only significantly affected by cultivars and by the interaction between fertilization and time, whereas caffeic acid content was significant affected by the interactions between cultivars and time and between doses of $\mathrm{N}$ and time (Table 1).

The Caiuá cultivar exhibited higher concentrations of ferulic acid than the Baianinha cultivar (Table 2). This suggests that the content of this secondary compound is related to genetic factors of the cassava plants, as indicated by Ramos et al. (2011). This acid is present in plant tissues, and 
has inhibitory effects on the growth of fungi and the production of mycotoxins. Moreover, studies have reported its importance as a mechanism of selfpreservation, because it strengthens the resistance of the cell wall and protects it from damage caused by microbes and solar radiation (EKMEKCIOGLU et al., 1998; SOUZA et al., 2010). Thus, cultivars with higher contents of this compound may be used in genetic improvement programs, with the aim of selecting materials that are resistant/tolerant to agricultural pests or abiotic factors.

Table 1. Mean square values of the variables rutin, caffeic acid, p-coumaric acid, and ferulic acid in cassava cultivars according to the doses of $\mathrm{N}$, at distinct collection times after nitrogen fertilization. Londrina, 2016.

\begin{tabular}{cccccc}
\hline & G.L & Ferulic acid & Caffeic acid & p-Coumaric acid & Rutin \\
\hline Cultivar & 1 & $0.00687^{*}$ & $0.000042^{*}$ & $0.01021^{*}$ & $2.29728^{*}$ \\
Fertilization & 3 & $0.00036^{\mathrm{n} / \mathrm{s}}$ & $0.000043^{*}$ & $0.00178^{*}$ & $1.88372^{*}$ \\
$\mathrm{C} \times \mathrm{F}$ & 3 & $0.00041^{\mathrm{n} / \mathrm{s}}$ & $0.000007^{\mathrm{n} / \mathrm{s}}$ & $0.00248^{*}$ & $1.00349^{*}$ \\
Time & 2 & $0.00022^{\mathrm{n} / \mathrm{s}}$ & $0.000271^{*}$ & $0.00132^{*}$ & $0.26197^{\mathrm{n} / \mathrm{s}}$ \\
$\mathrm{C} \times \mathrm{T}$ & 2 & $0.00007^{\mathrm{n} / \mathrm{s}}$ & $0.00004^{*}$ & $0.00045^{*}$ & $1.93567^{*}$ \\
$\mathrm{~F} \times \mathrm{T}$ & 6 & $0.00045^{*}$ & $0.000043^{*}$ & $0.00119^{*}$ & $0.6292^{*}$ \\
$\mathrm{C} \times \mathrm{F} \times \mathrm{T}$ & 6 & $0.00040^{\mathrm{n} / \mathrm{s}}$ & $0.000007^{\mathrm{n} / \mathrm{s}}$ & $0.00157^{*}$ & $1.19713^{*}$ \\
\hline Mean & & 0.0160 & 0.0087 & 0.1754 & 1.3215 \\
$\mathrm{CV}(\%)$ & & 33.46 & 32.50 & $37,57$. & 29.30 \\
\hline
\end{tabular}

*, significant at $5 \%$ probability by Tukey's test; $\mathrm{n} / \mathrm{s}$, non-significant at $5 \%$ probability by Tukey's test.

Table 2. Ferulic acid contents in apical leaves of the Baianinha and Caiuá cassava cultivars. Londrina, 2016.

\begin{tabular}{cc}
\hline Cultivar & Ferulic acid \\
\hline Baianinha & $0.0086 \mathrm{~b}$ \\
Caiuá & $0.0239 \mathrm{a}$ \\
\hline
\end{tabular}

Means followed by the same lowercase letters in the column were not significantly different by Tukey's test $(\mathrm{p} \leq 0.05)$.

In the interaction between the fertilization and time of leaf collection, a quadratic fit was only obtained at $30 \mathrm{~d}$ after nitrogen fertilization (Figure 1 ), with the minimum response of the compound occurring at a dose of $70 \mathrm{~kg} \mathrm{ha}^{-1}$. Data obtained by Ramos et al. (2011) showed that the contents of antioxidant flavonoids, including ferulic acid, in the ethanolic extract and in the hot aqueous extract of rosella leaves were significantly affected by the addition of poultry litter (substrate rich in $\mathrm{N}$ ) to the plant crop. On average, there was a $18 \%$ increase in the hot aqueous extract content and a $16 \%$ increase in the ethanolic extract content between data obtained with and without poultry litter. According to these studies, organic fertilization increases the soil's cation exchange capacity (CTC), thereby increasing the $\mathrm{pH}$ and decreasing the aluminum content. Therefore, there is an increase in the availability of nutrients introduced through mineral fertilizers, which contributes to plant health and diversifies the production of active substances by bacteria, such as phenols and antibiotics (KIEHL, 2008). 
Regarding caffeic acid, a significant difference between the two cultivars was only observed at 15 $\mathrm{d}$ after nitrogen fertilization, with the highest values being detected in the leaves of Baianinha (Table 3). In this cultivar, there was a decrease in caffeic acid content over time, and the lowest value occurred at $45 \mathrm{~d}$ after the application of N. In the Caiuá cultivar, the contents of caffeic acid were significantly higher at 15 and $30 \mathrm{~d}$ than at $45 \mathrm{~d}$ after the application of $\mathrm{N}$. The effect of applying $\mathrm{N}$ was observed in the shortterm, and did not persist in the long-term. This may be explained by the way it was applied to the pots, because although the irrigation performed after the addition of $\mathrm{N}$ favored the availability of the nutrient to the plants during this period, daily irrigation may have favored leaching over time.

Figure 1. Ferulic acid contents in leaves of the Caiuá cassava cultivar submitted to increasing doses of nitrogen at different times of the assessment. Londrina, 2016.

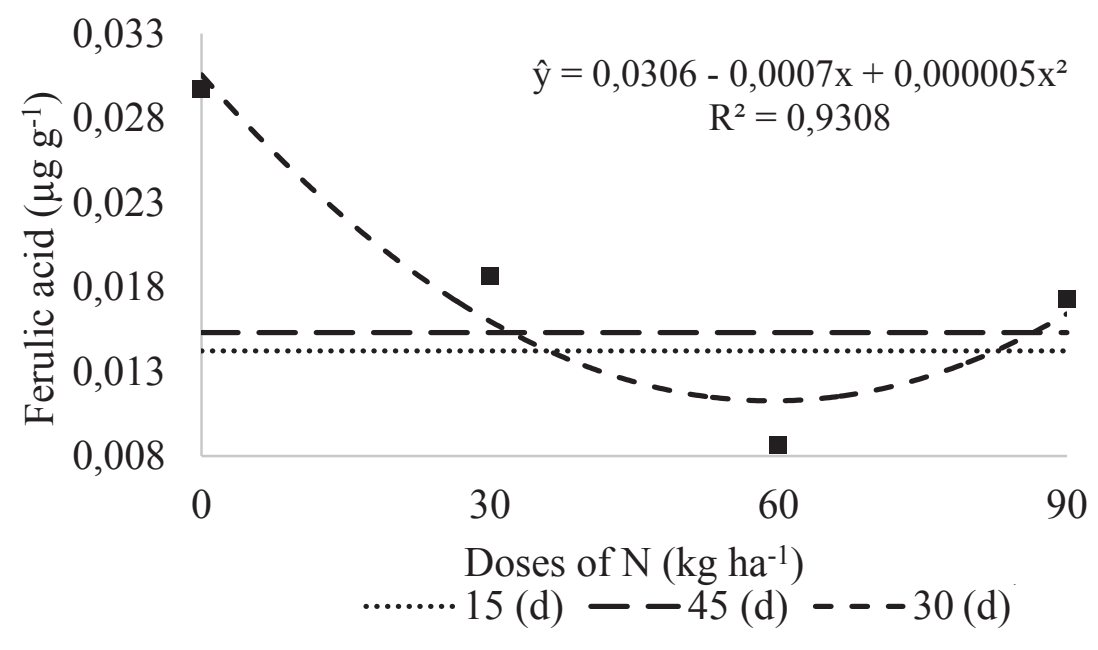

Table 3. Contents of caffeic acid in apical leaves of the cassava cultivars at distinct times after the application of nitrogen fertilization. Londrina, 2016.

\begin{tabular}{cccc}
\hline \multirow{2}{*}{ Cultivar } & \multicolumn{3}{c}{ Time $(\mathrm{d})$} \\
\cline { 2 - 4 } & 15 & 30 & 45 \\
\hline Baianinha & $0.0126 \mathrm{a} \mathrm{A}$ & $0.0094 \mathrm{a} \mathrm{B}$ & 0.0062 a C \\
Caiuá & $0.0093 \mathrm{~b} \mathrm{~A}$ & $0.0094 \mathrm{a} \mathrm{A}$ & 0.0056 a B \\
\hline
\end{tabular}

*Means followed by the same uppercase letters in the row and lowercase letters in the column were not significantly different by Tukey's test $(p \leq 0.05)$.

Plant secondary compounds are significantly affected by the fertilization, environmental conditions, and degree of maturation of the plant, in addition to genetic factors (RAMOS et al., 2011). This was the case with caffeic acid, which, regardless of the cultivar, exhibited an increasing linear response to the doses of $\mathrm{N}$ at $15 \mathrm{~d}$ after the application of $\mathrm{N}$, with a content peak at a dose of 90 $\mathrm{kg} \mathrm{ha}^{-1}$. No differences were observed between the remaining collection times (Figure 2). At 30 and 45 
$\mathrm{d}$, leaching of the nutrient from the pots probably occurred because of daily irrigation, thereby making the added N unavailable to the plants. Similar results were obtained by Malta et al. (2003) in their study of the effects of sources and doses of $\mathrm{N}$ on the contents of chlorogenic acids in coffee beans. According to these authors, the contents of chlorogenic acids (caffeic, p-coumaric, and ferulic acids) increased with increasing doses of N. However, Fernandes
(2007) assessed the relationships between doses of $\mathrm{N}$ and $\mathrm{K}$, concentrations of phytochemical compounds, and attack by the cochineal insect Coccus viridis Green (Hemiptera: Coccidae) in coffee plants, and reported that an increase in the doses of $\mathrm{N}$ and $\mathrm{K}, 11$ months after supplying plants with a nutrient solution, directly increased $\mathrm{N}$ content in the leaves, which in turn led to a decrease in caffeic acid content.

Figure 2. Mean caffeic acid contents in apical leaves of the Baianinha and Caiuá cassava cultivars submitted to increasing doses of nitrogen at different times of the assessment. Londrina, 2016.

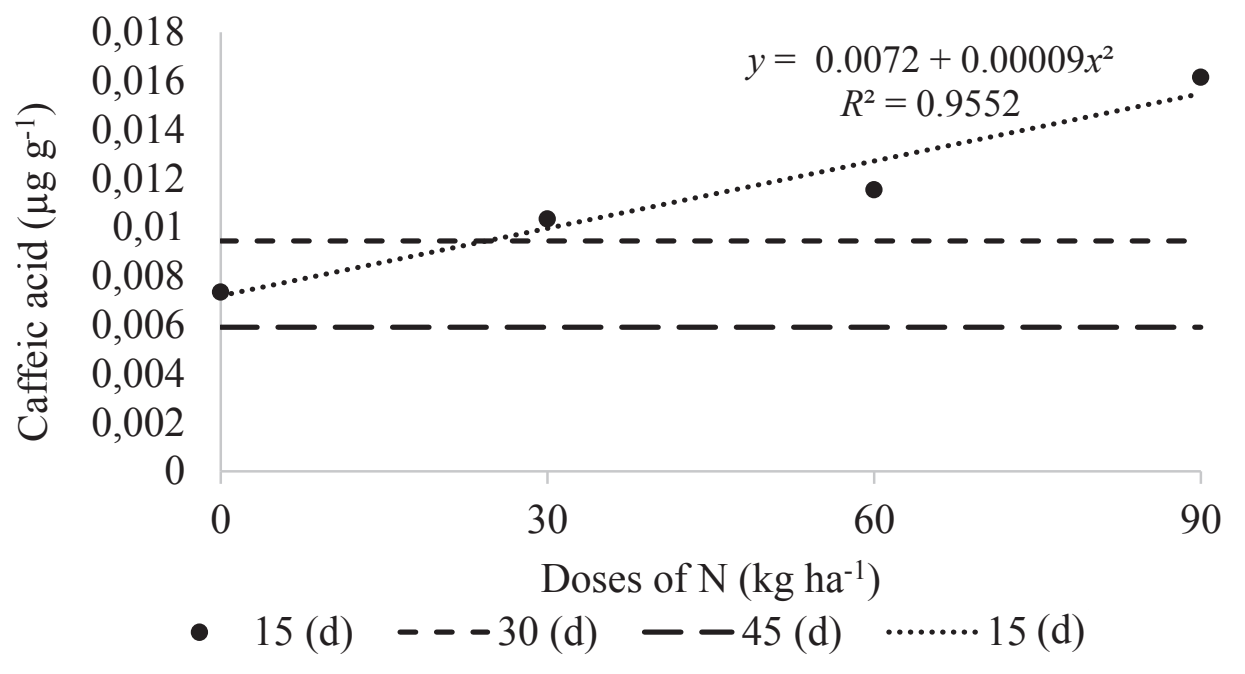

The results that contradict those of the present study may be explained by differences in assessment times or even by the use of supplementation with $\mathrm{K}$, in addition to $\mathrm{N}$, which was not performed in the present study. The highest contents of p-coumaric acid in the Baianinha cultivar were observed at 30 and $45 \mathrm{~d}$ after the application of $\mathrm{N}$ (at the $0 \mathrm{~kg} \mathrm{ha}^{-1}$ dose) and at $30 \mathrm{~d}$ (at the $30 \mathrm{~kg} \mathrm{ha}^{-1}$ dose) (Table 4). At the $60 \mathrm{~kg} \mathrm{ha}^{-1}$ dose, the highest content was obtained $15 \mathrm{~d}$ after the application of $\mathrm{N}$. In the Caiuá cultivar, no changes were observed in the contents of p-coumaric acid between the different assessment times. 
Table 4. Contents of p-coumaric acid and rutin in apical leaves of the Baianinha and Caiuá cassava cultivars, according to the different doses of nitrogen and collection times. Londrina, 2016.

\begin{tabular}{|c|c|c|c|c|c|c|c|c|}
\hline \multirow{3}{*}{$\begin{array}{l}\text { Time } \\
\text { (d) }\end{array}$} & \multicolumn{8}{|c|}{ p-Coumaric acid } \\
\hline & \multicolumn{2}{|c|}{$0 \mathrm{~kg} \mathrm{ha}^{-1}$} & \multicolumn{2}{|c|}{$30 \mathrm{~kg} \mathrm{ha}^{-1}$} & \multicolumn{2}{|c|}{$60 \mathrm{~kg} \mathrm{ha}^{-1}$} & \multicolumn{2}{|c|}{$90 \mathrm{~kg} \mathrm{ha}^{-1}$} \\
\hline & Baian. & Caiuá & Baian. & Caiuá & Baian. & Caiuá & Baian. & Caiuá \\
\hline 15 & $0.015 \mathrm{bA}$ & $0.014 \mathrm{aA}$ & $0.010 \mathrm{bA}$ & $0.010 \mathrm{aA}$ & $0.093 \mathrm{aA}$ & $0.007 \mathrm{aB}$ & $0.005 \mathrm{aA}$ & $0.015 \mathrm{aA}$ \\
\hline 30 & $0.035 \mathrm{aA}$ & $0.018 \mathrm{aB}$ & $0.054 \mathrm{aA}$ & $0.008 \mathrm{aB}$ & $0.046 \mathrm{bA}$ & $0.006 \mathrm{aB}$ & $0.009 \mathrm{aA}$ & $0.008 \mathrm{aA}$ \\
\hline 45 & $0.027 \mathrm{aA}$ & $0.003 \mathrm{aB}$ & $0.020 \mathrm{bA}$ & $0.003 \mathrm{aB}$ & $0.015 \mathrm{cA}$ & $0.009 \mathrm{aB}$ & $0.009 \mathrm{aA}$ & $0.009 \mathrm{aA}$ \\
\hline Time & \multicolumn{8}{|c|}{ Rutin } \\
\hline (d) & \multicolumn{2}{|c|}{$0 \mathrm{~kg} \mathrm{ha}^{-1}$} & \multicolumn{2}{|c|}{$30 \mathrm{~kg} \mathrm{ha}^{-1}$} & \multicolumn{2}{|c|}{$60 \mathrm{~kg} \mathrm{ha}^{-1}$} & \multicolumn{2}{|c|}{$90 \mathrm{~kg} \mathrm{ha}^{-1}$} \\
\hline & Baian. & Caiuá & Baian. & Caiuá & Baian. & Caiuá & Baian. & Caiuá \\
\hline 15 & $1.813 \mathrm{aA}$ & $1.608 \mathrm{aA}$ & $0.683 \mathrm{bA}$ & $1.124 \mathrm{aA}$ & $1.235 \mathrm{aA}$ & $1.205 \mathrm{aA}$ & $1.419 \mathrm{aA}$ & $2.193 \mathrm{aA}$ \\
\hline 30 & $1.597 \mathrm{aA}$ & $1.643 \mathrm{aA}$ & $1.918 \mathrm{aA}$ & $0.455 \mathrm{bB}$ & $1.285 \mathrm{aA}$ & $1.445 \mathrm{aA}$ & $1.732 \mathrm{aA}$ & $0.436 \mathrm{bB}$ \\
\hline 45 & $1.427 \mathrm{aA}$ & $1.451 \mathrm{aA}$ & $1.089 \mathrm{bA}$ & $0.459 \mathrm{bB}$ & $1.446 \mathrm{aA}$ & $1.653 \mathrm{aA}$ & $1.939 \mathrm{aA}$ & $0.450 \mathrm{Bb}$ \\
\hline
\end{tabular}

*Means followed by the same lowercase letters in the column and uppercase letters in the row were not significantly different by Tukey's test $(p \leq 0.05)$., between the cultivars and doses at different assessment times.

There were no statistical differences between the cultivars regarding p-coumaric acid at the doses of 0,30 , and $90 \mathrm{~kg} \mathrm{ha}^{-1}$ at $15 \mathrm{~d}$ post-fertilization. At a dose of $60 \mathrm{~kg} \mathrm{ha}^{-1}$, the Baianinha cultivar had a higher concentration of this compound than the Caiua cultivar. In addition, at 30 and $45 \mathrm{~d}$, the Baianinha cultivar exhibited higher contents of the compound when 0,30 , and $60 \mathrm{~kg} \mathrm{ha}^{-1}$ of $\mathrm{N}$ were applied. At the $90 \mathrm{~kg} \mathrm{ha}^{-1}$ dose, the concentrations of this acid did not differ between the two cultivars.

The concentration of rutin in the Baianinha cultivar at the 0,60 , and $90 \mathrm{~kg} \mathrm{ha}^{-1}$ doses of $\mathrm{N}$ did not differ between the times of assessment after the application of $\mathrm{N}$ (Table 4). At the $30 \mathrm{~kg} \mathrm{ha}^{-1}$ dose, the highest content of the compound was obtained at $30 \mathrm{~d}$ after fertilization. In the Caiuá cultivar there was no difference between the assessment times when the 0 and $60 \mathrm{~kg} \mathrm{ha}^{-1}$ doses were used. At the 30 and $90 \mathrm{~kg} \mathrm{ha}^{-1}$ doses of $\mathrm{N}$, the highest content of the flavonoid was observed at $15 \mathrm{~d}$ after the application of $\mathrm{N}$.

At $15 \mathrm{~d}$, there were no statistical differences in the amounts of rutin between the cultivars when the used doses of $\mathrm{N}$ were 0,30 , and $60 \mathrm{~kg} \mathrm{ha}^{-1}$. At 30 and $45 \mathrm{~d}$, there were no statistical differences at the doses of 0 and $60 \mathrm{~kg} \mathrm{ha}^{-1}$. When using the $90 \mathrm{~kg}$ ha $^{-1}$ dose, the Caiua cultivar exhibited the highest content of the compound at $15 \mathrm{~d}$. The Baianinha cultivar exhibited the highest contents at 30 and 45 $\mathrm{d}$ and at the 30 and $60 \mathrm{~kg} \mathrm{ha}^{-1}$ doses. These results may be related to the genetic factors of the cultivars; because the Caiuá cultivar is better adapted to sandy soils, it exhibited a short-term response to the $\mathrm{N}$ supplied to the plants, whereas the Baianinha cultivar took a longer time to respond to nitrogen fertilization.

In the regression analysis of the Baianinha cultivar, the quadratic fit showed a maximum response of p-coumaric acid at $30 \mathrm{~d}$, at the $27.5 \mathrm{~kg} \mathrm{ha}^{-1}$ dose, whereas at $45 \mathrm{~d}$ there was a decreasing linear fit. In the Caiuá cultivar, there was no significant fit in response to the different doses of $\mathrm{N}$ (Figure 3). p-Coumaric acid is associated with microorganisms the rumen, and can be toxic if high concentrations are consumed (CARVALHO; PIRES, 2008). Similar data were obtained by Marschner (1995), who concluded that high concentrations of $\mathrm{N}$ decreased the production of some phenolic compounds that have a fungistatic action, including p-coumaric 
acid, and lignification of leaves, thereby reducing the resistance to obligate parasites while having no action on facultative parasites. Therefore, the use of cultivars with high contents of this compound may be troublesome for cassava producers who use the aerial part of the plant for animal feeding.

Regarding rutin in the Baianinha cultivar, there was a quadratic fit at 15 and $45 \mathrm{~d}$, with a minimum response at doses of $43.75 \mathrm{~kg} \mathrm{ha}^{-1}$ and $36.25 \mathrm{~kg}$ $\mathrm{ha}^{-1}\left(0.9375 \mu \mathrm{g} \mathrm{g}^{-1}\right.$ and $1.1000 \mu \mathrm{g} \mathrm{g}^{-1}$ of rutin, respectively). In the Caiua cultivar, the quadratic fit was obtained at $15 \mathrm{~d}$, with a minimum value at the $38.37 \mathrm{~kg} \mathrm{ha}^{-1}$ dose (Figure 4).
The decrease in the rutin content with the increase in the $\mathrm{N}$ dose was probably the result of nitrogen metabolism, which is related to the carbon/nutrient balance. The greater vegetative growth of the aerial part of the cassava plant with the production of new leaves decreases the number of organic compounds designated to the synthesis of rutin. Moreover, $\mathrm{N}$ directly alters the amount and quality of nutrients present in the plant. This effect occurs because it is more available in the phloem, thus increasing the contents of free amino acids, soluble carbohydrates, and single-chain lipids, which are easily digestible food sources for phytophagous insects, such as $P$. manihoti (MATTSON, 1980; BUCHANAN et al., 2000; FERNANDES, 2007).

Figure 3. p-Coumaric acid contents in apical leaves of the Baianinha cassava cultivar submitted to increasing doses of nitrogen at different times of the assessment. Londrina, 2016.

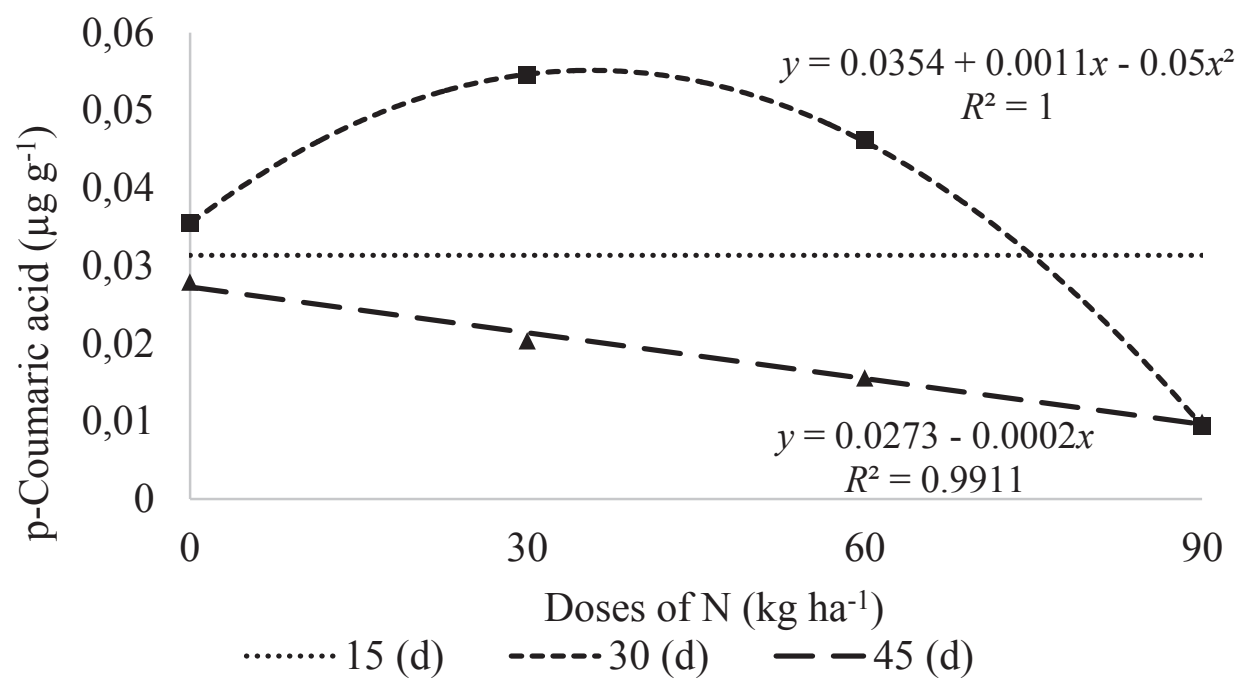


Figure 4. Rutin contents in apical leaves of the Baianinha (A) and Caiuá (B) cassava cultivars submitted to increasing doses of nitrogen at different times of the assessment. Londrina, 2016.
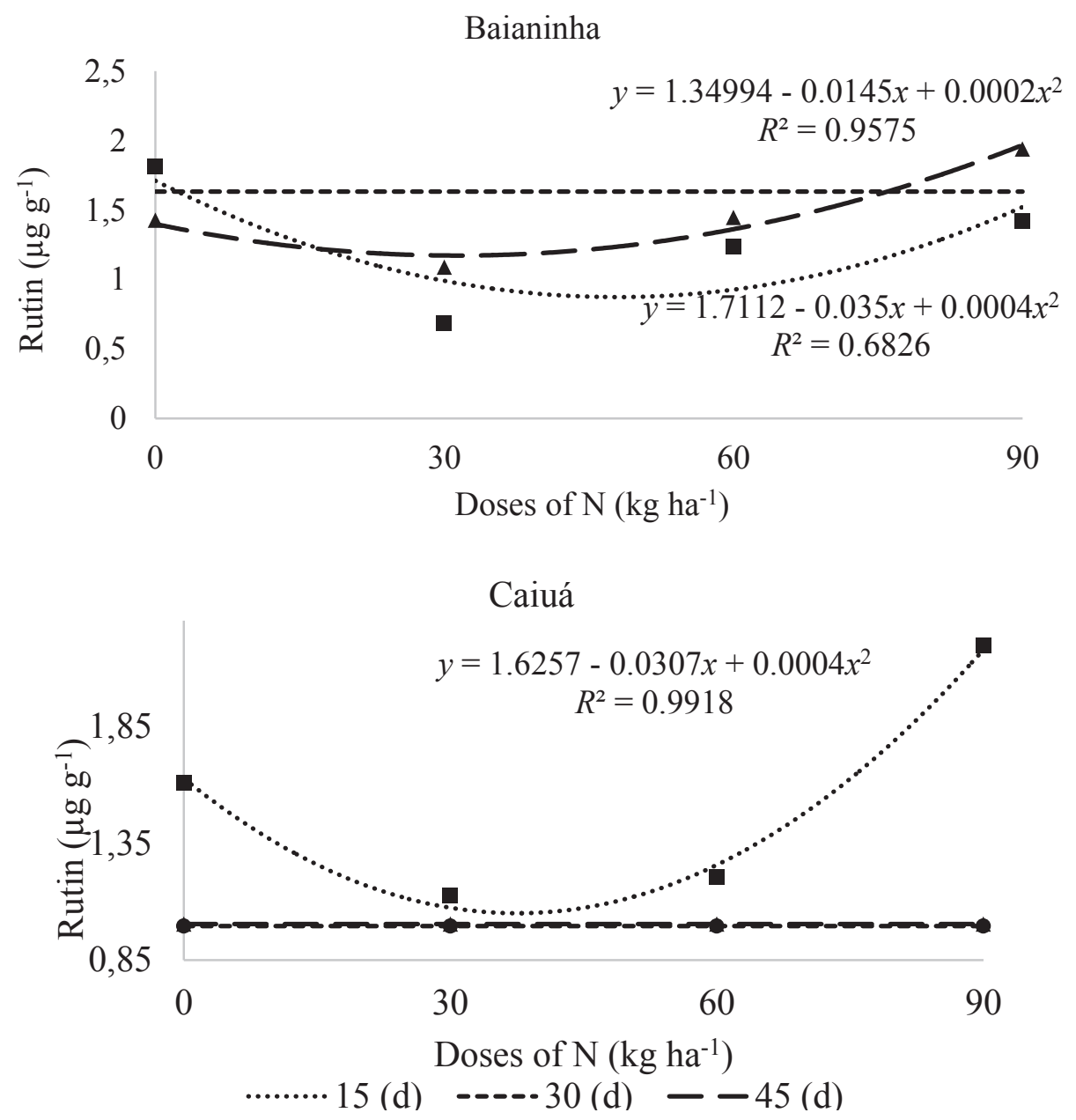

Similar results were obtained by Malta et al. (2003), who observed a significant effect of the interaction between sources and doses of $\mathrm{N}$ on total phenolic compounds. Ammonium nitrate and ammonium sulfate sources produced similar effects, with a decrease in the concentration of total phenolic compounds up to doses of $161 \mathrm{~kg} \mathrm{ha}^{-1}$ and $138 \mathrm{~kg}$ $\mathrm{ha}^{-1}$ of $\mathrm{N}$ (total contents of phenolic compounds were $6.82 \%$ and $6.15 \%$, respectively).

Moreover, the use of high doses of $\mathrm{N}$ in fertilization reduces the physical barriers to the feeding of sucking insects. In leaves, these barriers are the thickness of the cuticle, epidermis, and parenchyma, and the rigidity of the cell walls of these tissues, which hinder the insertion of the sucking mouthpart into the phloem. These morphological barriers are composed of waxes, complex carbohydrates, and long-chain proteins, whose contents in the leaves decrease with the application of high doses of nitrogen during fertilization (MARSCHNER, 1995; PHELAN et al., 1996; TAIZ; ZEIGER, 2010). Hogendorp et al. (2006) reported that an increase in nitrogen fertilization led to an increase in the attack frequency and reproduction of the citrus mealybug, Planococcus citri (Risso) (Hemiptera: Pseudococcidae), on coleus, Solenostemon 
scutellarioides. However, plants that are deficient in nitrogen can allocate a higher amount of carbon for the production of plant defense secondary compounds (HERMANS; MATTSON, 1992).

The production of phenolic compounds is often associated with the response to plant-environment interaction mechanisms, which may be triggered under stress conditions; this explains the data obtained in this study. Mineral nutrition is one of the most important stress factors and, according to Freitas et al. (2008) and Leite et al. (2012), mineral deficiency may lead to the increased or decreased production of phenolic compounds. On the other hand, the increase in phenolic compounds relative to the availability of nutrients in the soil varies between plant species, and with the different biosynthesis pathways of these compounds (HAUKIOJA et al., 1998).

A balanced availability of nutrients is essential for the plant to recover from attacks by pests through mechanisms of compensatory growth. This compensation is related to the increase in photosynthesis as a result of due to increased nitrogen fertilization, which allows the plant to better tolerate the attack (TRUMBLE et al., 1993). Thus, more studies with longer testing periods are necessary to clarify the behavior of secondary compounds in response to nitrogen fertilization in cassava cultivars, as well as their relationship with the plant's development, defense mechanisms, and tolerance to attacks by pest insects.

\section{Conclusion}

The Caiuá cultivar accumulated a higher ferulic acid content. The caffeic acid content decreased over time after the application of $\mathrm{N}$ in both cultivars. The rutin content in the Baianinha and Caiuá cassava cultivars was not affected by increasing the $\mathrm{N}$ dose. At the $90 \mathrm{~kg} \mathrm{ha}^{-1}$ dose, the cultivars exhibited a lower p-coumaric acid content $30 \mathrm{~d}$ after nitrogen fertilization.

\section{Acknowledgments}

We thank the Laboratory of Chemical Ecology of Embrapa Soja for the technical and scientific support.

\section{References}

BELLOTTI, A. C.; SMITH, L.; LAPOINTE, S. L. Recent advances in cassava pest management. Annual Review of Entomology, New York, v. 44, n. 1, p. 343-370, 1999.

BUCHANAN, B. B.; GRUISSEM, W.; JONES, R. L. Biochemistry and molecular biology of plants. Rockville: American Society of Plant Physiologists, 2000. 1366 p.

BURR, I. W.; FOSTER, L. A. A test for equality of variances. West Lafayette: University of Purdue, 1972. 26 p. (Mimeo series, n. 282).

CALATAYUD, P. A.; MÚNERA, D. F. Defensas naturales de la yuca a las plagas e artrópodos. In: OSPINA, B.; CEBALLOS, H. La yuca en el tercer milenio: sistemas modernos de producción, procesamiento, utilización y comercialización. Cali: CIAT, 2002. p. 250-254.

CARVALHO, G. G. P.; PIRES, A. J. V. Organização dos tecidos de plantas forrageiras e suas implicações para os ruminantes. Archivos de Zootecnia, Córdoba, v. 57, n. 1, p. 13-28, 2008.

CARVALHO, P. C. L.; FUKUDA, W. M. G. Estrutura da planta e morfologia. In: SOUZA, L. de S. (Coord.). Aspectos socioeconômicos e agronômicos da mandioca. Cruz das Almas: EMBRAPA Mandioca e Fruticultura, 2006. $817 \mathrm{p}$.

EKMEKCIOGLU, C.; FEYERTAG, J.; MARKTL, W. Cinnamic acid inhibits proliferation and modulates brush border membrane enzyme activities in Caco-2 cells. Cancer Lett, Heidelberg, v. 128, n. 2, p. 137-144, 1998.

FERNANDES, F. L. Efeito de nitrogênio e de potássio na interação entre Coccus viridis e Coffea arábica. 2007. Dissertação (Mestrado em Agronomia) - Universidade Federal de Viçosa, Viçosa, MG.

FREITAS, M. S. M.; MONNERAT, P. H.; VIEIRA, I. J. C. Mineral deficiency in passiflora alata curtis: vitexin bioproduction. Journal of Plant Nutrition, Philadelphia, v. 31, n. 10, p. 1844-1854, 2008.

GERSHENZON, J. Changes in the levels of plant secondary metabolites under water and nutrient stress. In: TIMMERMANN, B. N.; STEELINK, C.; LOEWUS, F. A. (Ed.). Phytochemical adaptations to stress, recent advances in photochemistry. New York: Plenum, 1984. v. 18, p. $273-320$. 
HAUKIOJA, E.; OSSIPOV, V.; KORICHEVA, J.; HONKANEN, T.; LARSSON, S.; LEMPA, K. Biosynthetic origin of carbon-based secondary compounds: cause of variable responses of woody plants to fertilization? Chemo Ecology, Darmstadt, v. 8, n. 3, p. 133-139, 1998.

HERMANS, D. A.; MATTSON, W. J. The dilemma of plants: to grow or to defend. The Quarterly Review of Biology, Chicago, v. 67, n. 3, p. 478-500, 1992.

HOGENDORP, B. K.; CLOYD, R. A.; SWIADER, J. M. Effect of nitrogen fertility on reproduction and development of citrus mealybug, planococcus citri risso (Homoptera: Pseudococcidae), feeding on two colors of coleus, Solenostemonscutellarioides L. Codd. Environmental Entomology, New York, v. 35, n. 2, p. 201-211, 2006.

KIEHL, E. J. Adubação orgânica: 500 perguntas e respostas. Piracicaba: Degaspari, 2008. 227 p.

LEITE, G. L. D.; SILVA, F. W. S.; GUANABENS, R. E. M.; FERNANDES, L. A.; FIGUEIREDO, L. S.; SILVA, L. F. NPK and flavonoids affecting insect populations in Dimorphandra mollis seedlings. Acta Scientiarum Agronomy, Maringá, v. 34, n. 1, p. 17-22, 2012.

LORENZI, J. O. Mandioca. Campinas: CATI, 2003. 116 p. (Boletim técnico, 245).

MALAVOLTA, E.; VITTI, G. C.; OLIVEIRA, S. A. Avaliação do estado nutricional de plantas: princípios e aplicações. Piracicaba: Potafos, 1997. 308 p.

MALTA, M. R.; NOGUEIRA, F. D.; GUIMARÃES, P. T. G. Composição química, produção e qualidade do café fertilizado com diferentes fontes e doses de nitrogênio. Ciência Agrotecnológica, Lavras, v. 27, n. 6, p. 12461252, 2003.

MARSCHNER, H. Mineral nutrition of higher plants. $2^{\text {th }}$ ed. San Diego: Academic Press, 1995. 889 p.

MATTOS, P. L. P.; BEZERRA, V. S. Cultivo da mandioca para o estado do Amapá. Cruz das Almas: EMBRAPA Mandioca e Fruticultura Sistemas de Produção. Crus das Almas: Embrapa, jan. 2003. https://sistemasdeproducao. cnptia.embrapa.br/FontesHTML/Mandioca/mandioca amapa/sementes.htm

MATTSON, W. J. Herbivory in relation to plant nitrogen content. Annual Review Ecology and Systematic, New York, v. 11, n. 1, p. 119-161, 1980.

OLIVEIRA, N. T.; UCHÔA, S. C. P.; ALVES, J. M. A.; SEDIYAMA, T.; ALBUQUERQUE, J. A. A.; SOUZA, E. D.; MELVILLE, C. C. Ácido cianídrico em tecidos de mandioca em função da idade da planta e adubação nitrogenada. Pesquisa Agropecuária Brasileira, Brasília, v. 47, n. 10, p. 1436-1442, 2012.

PARENTE, R. C. P. Aspectos da análise de resíduos. 1984. Dissertação (Mestrado em Estatística e Experimentação Agronômica) - Escola Superior de Agricultura Luiz de Queiroz, ESALQ/USP, Piracicaba.

PARSA, S.; TAKUMASA, K.; WINOTAI, A. The cassava mealybug (Phenacoccus manihoti) in Asia: first records, potential distribution, and an identification key. PLoS ONE, San Francisco, v. 7, n. 10, e47675 2012.

PHELAN, P. L.; NORRIS, K. H.; MASON, J. F. Soilmanagement history and host preference by Ostrinia nubilalis: evidence for plant mineral balance mediating insect-plant interactions. Environmental Entomology, New York, v. 25, n. 6, p. 1329-1336, 1996.

PIETROWSKI, V.; RINGENBERGER, R.; RHEINHEIMER, A. R.; BELLON, P. P.; GAZOLA, D.; MIRANDA, A. M. Insetos-praga na cultura da mandioca na região Centro-Sul do Brasil. Marechal Candido Rondon: Unioeste, 2010. p. 20-23.

RAMOS, D. D.; VIEIRA, M. do C.; FORMAGIO, A. S. N.; CARDOSO, C.A. L.; RAMOS, D. D.; CARNEVALI, T. de O. Atividade antioxidante de Hibiscus sabdariffa L. em função do espaçamento entre plantas e da adubação orgânica. Ciência Rural, Santa Maria, v. 41, n. 8, p. 1331-1336, 2011.

RHEINHEIMER, A. R. Resistencia de variedades de mandioca à cochonilha Phenacoccus manihoti (MatleFerrero) e sua influência sobre o parasitoide Anagyrus lipezi (De Santis). 2013. Tese (Doutorado em agronomia) - Universidade Estadual do Oeste do Paraná, Marechal Candido Rondon.

SANTOS, M. F.; PAULA-MORAES, S. V.; VIEIRA, E. A.; FIALHO, J. F.; OLVEIRA, C. M.; TAKADA, S. C. S.; SOUZA, A. A. C. Teor de ácido cianídrico (HCN) como parâmetro para seleção de possíveis acessos de mandioca resistentes ao percevejo de renda. In: SIMPÓSIO INTERNACIONAL SAVANAS TROPICAIS, SIMPÓSIO NACIONAL CERRADO, 2., 9., 2008, Brasília. Anais... Planaltina: EMBRAPA Cerrados, 2008. p. 561-567.

SCHALLER, A. Induced plant resistance to herbivory. Hardcover: Springer, 2008. 464 p.

SHAPIRO, S. S.; WILK, M. B. An analysis of variance test for normality. Biometrika, New York, v. 52, n. 3/4, p. 591-611, 1965.

SOLOMONSON, H. P.; BARBER, J. M. Assimilatory nitrate reductase: funcional properties and regulation. Annual Review of Plant Physiology, California, v. 41, n. 1, p. 225-253, 1990 . 
SOUZA, M. M. de; OLIVEIRA, M. dos S.; ROCHA, M. da; FURLONG, E. B. Avaliação da atividade antifúngica de extratos fenólicos de cebola, farelo de arroz e microalga Chlorella phyrenoidosa. Ciência e Tecnologia de Alimentos, Campinas, v. 30, n. 3, p. 680-685, 2010.

STATISTICAL ANALYSIS SYSTEM INSTITUTE SAS Institute. SAS/STAT: user's guide. Version 9.2. Cary: SAS Institute, 2009. 7869 p.

STEEL, R. G. D.; TORRIE, J. H. Principles and procedures of statistics. With special reference to the biological sciences. New York: McGraw-Hill, 1960. 481 p.

TAIZ, L.; ZEIGER, E. Plant physiology. $5^{\text {th }}$ ed. Sunderland: Sinauer Associates, Inc., 2010. 782 p.

TAKAHASHI, M.; GONÇALO, S. A cultura da mandioca. 2. ed. Paranavaí: Olímpica, 2005. 116 p.
TRUMBLE, J. T.; KOLODNY-HIRSCH, D. M.; TING, I. P. Plant compensation for arthropod herbivory. Annual Review of Entomology, New York, v. 38, n. 1, p. 93-119, 1993.

TUKEY, J. W. One degree of freedon for non-additivity. Biometrics, Washington, v. 5, n. 3, p. 232-242, 1949.

VETTER, J. Plant cyanogenic glycosides. Toxicon, Queensland, v. 38, n. 1, p. 11-36, 2000.

WATERMAN, P. G.; MOLE, S. Extrinsic factors influencing production of secondary metabolites in plants. In: BERNAYS, E. A. (Ed.). Insect-plant interactions. Boca Raton: CRC Press, 1989. v. 1, p. 107-134.

ZAGROBELNY, M.; BAK, S.; RASMUSSEM, A. V.; JORGENSEN, B.; NAUMANN, C. M.; MOLLER, B. L. Cyanogenic glucosides na plant-insect interactions. Phytochemistry, New York, v. 65, n. 3, p. 293-306, 2004. 
